\title{
LOCAL ETHNIC MALAY COMMUNITY KNOWLEDGE IN TRADITIONAL MEDICINE UTILIZATION AND ITS CONSERVATION STRATEGY IN EAST BELITUNG REGENCY, INDONESIA
}

\author{
HENRI $^{*}$ AND ERIKA ERPANDI \\ Department of Biology, Faculty of Agriculture, Fisheries and Biology, Universitas Bangka Belitung, Bangka, 33172, \\ Indonesia \\ *Email: biology.henry@gmail.com
}

Accepted December 21, 2020 / Approved February 23, 2021

\begin{abstract}
Belitung Malay is the largest ethnic group in the East Belitung Regency which is rich in biodiversity. In daily life, the people of East Belitung utilize biological resources for various necessities of life, including the utilization for health maintenance and treatment. However, along with the changing times and technological developments in the health sector, there are some changes in society in the use of biodiversity as traditional medicine. This study aims to examine the knowledge and perceptions of the Belitung Malay ethnic community on the use of traditional medicines. The method used in this study is a semi-structured interview with ethnographic techniques. Informants were selected using purposive sampling, in which they were considered to have a lot of knowledge about traditional medicine and its processing, such as traditional leaders, tribal chiefs, village heads, herbalists, and massage workers. The data were analyzed using descriptive analysis. The results of the interview show that people still use traditional medicine a lot. Traditional medicine is sourced from plant and animal raw materials. Community trust in traditional medicines is still quite high as indicated in the use of medicinal plants based on use values reaching 0.64 and animal-sourced traditional medicines of 92.59 . Even though the use-value is high for the Malay ethnic community, it seems that the existence of traditional medicinal materials has become increasingly difficult and scarce to obtain. In this case, to obtain these medicinal ingredients, people must go far into the forest.
\end{abstract}

Key words: East Belitung, knowledge, medicinal animals, medicinal plants, traditional healers

\section{INTRODUCTION}

Ethnobiology, as a scientific discipline, has not been developed much in Indonesia, even though the use and management of biodiversity by traditional societies is still high (Vitalini et al. 2013; Iskandar 2016). Ethnobiological knowledge also forms the basis for understanding human relations with plants (ethnobiology) and animals (ethnozoology) (Narchi et al. 2014). The potential for plants and animals to be recognized as traditional medicinal ingredients is an integral part of human culture and society (Alves \& Souto 2011; Woerdenbag et al. 2012; Adorisio et al. 2016).

According to the Law No. 6/2012, traditional medicine is an ingredient made from minerals, plants, animals, or mixtures of various materials used as medicine by the community (Permenkes 2012). The World Health Organization (WHO) says that about $80 \%$ of people still trust plants and animals as a traditional medicine in the community where among the 252 essential chemicals, 11.1 percent comes from plants and 8.7 percent comes from animals (Verma et al. 2014). The world's population estimates that three-quarters of society cannot afford to buy modern medicines and depend on the use of traditional medicines (Ansari \& Inamdar 2010; Adorisio et al. 2016). Therefore, the biological resources available in nature are a cheap source of medicines for the community, and it is necessary to maintain the health of the community, especially the local community (Woerdenbag et al. 2012; Butt et al. 2015).

In general, community knowledge about traditional medicine comes from experience and skills that are inherited from one generation to the next one (Zahara 2017), delivered orally from parents to their children, as well as from the traditional elders of the community. However, the habit of delivering information verbally to the children that lack interest in it today causes the degradation of information for the future. As a result, knowledge of local wisdom, especially related to drugs, is increasingly endangered, given that it is only orally transmitted instead of any written form (Afriyansyah et al. 2016). Exploring the potential of local knowledge about traditional medicine can provide new information in selecting raw materials for medicines (Butt et al. 2015; Saudah et al. 2019). This drug knowledge is inherited from their ancestors and passed down across generations using local languages (Iskandar 2016). Traditional medicine is an integral part of human daily life regardless of the culture, time, or development of knowledge in a country (Adorisio et al. 2016; Addoun et al. 2018). The trend in the consumption of traditional medicines (herbal) is marked by the increasing value of its trade in the world market (Vijayakumar et al. 2015).

Several studies on traditional Bangka medicine have been carried out by the local people in South Bangka Regency (Henri et al. 2020), showing that local people still use plants for medicine in early childhood, featuring 55 plant species from 35 families which are 
dominated by the Euphorbiaceae family. Likewise, Afriyansyah et al. (2016) found the Lom tribe used 24 traditional medicines from 24 animals. While Oktavia (2012) revealed that the composition of vegetation and the potential of medicinal plants in the forest of East Belitung Regency is still very much. This condition is expected to be in line with the high level of knowledge of traditional medicine and the high perception of the benefits of traditional medicine. Therefore, the existence of plants and animals that have the potential as medicines can be maintained and utilized for the next generation. Perceptions and knowledge about traditional medicine can be implemented as input for the management of biological resources and ecosystems by applying local wisdom. Therefore, this study aims to find out the perceptions and knowledge of the East Belitung Malay ethnic community in traditional medicine.

\section{RESEARCH METHOD}

The study was conducted in East Belitung district which consists of seven subdistricts with 13 villages, namely: Manggar Subdistrict (Kurnia Jaya Village and Lalang Jaya Village), Damar Subdistrict (Sukamandi Village and Mempaya Village), Gantung Subdistrict (Gantung Village and Selinsing Village), Kelapa Kampit Subdistrict (Senyubuk Village and Cendil Village), Simpang Renggiang Subdistrict (Renggiang Village and Aik Madu Village), Simpang Pesak Subdistrict (Simpang Pesak Village), and Dendang Subdistrict (Dendang Village and Jangkang Village) (Figure 1).
Data on community knowledge about animals and plants as a traditional medicine in East Belitung Regency were collected through the following stages: conducting a field survey and observation to dig information from the community. The informants were selected using purposive sampling technique. The criteria for informants to be interviewed include: residents born in the study area, having knowledge of medicinal plants and animals, traditional ceremony performers, or traditional leaders (Shuaib et al. 2018; Oyeyemi et al. 2019). The age ranges of the informants follow Witjoro et al. (2016), namely 17-30 years (young), > 30-45 years (adults), > 45-49 years (middle age), and > 60 years (old). Then, the interview stage is intended for documentation of medicinal plants and animals for identification.

Informant Consensus Factor is used to measure homogeneity and consensus among informants in the use of medicinal plants to treat certain categories of disease (Faruque et al. 2018). It can also be used to identify the pharmacological importance of animal species collected and to analyze the level of agreement of informant knowledge about each disease category (Kim \& Song 2013) using the formula:

$$
\mathrm{ICF}=\mathrm{N}_{\mathrm{ur}}-\mathrm{N}_{\mathrm{t}} / \mathrm{N}_{\mathrm{ur}}-1
$$

Note:

$\mathrm{N}_{\mathrm{ur}}$ : total number of reported use for each disease category

$\mathrm{N}_{\mathrm{t}} \quad$ : number of plant or animal species reported for each reported disease

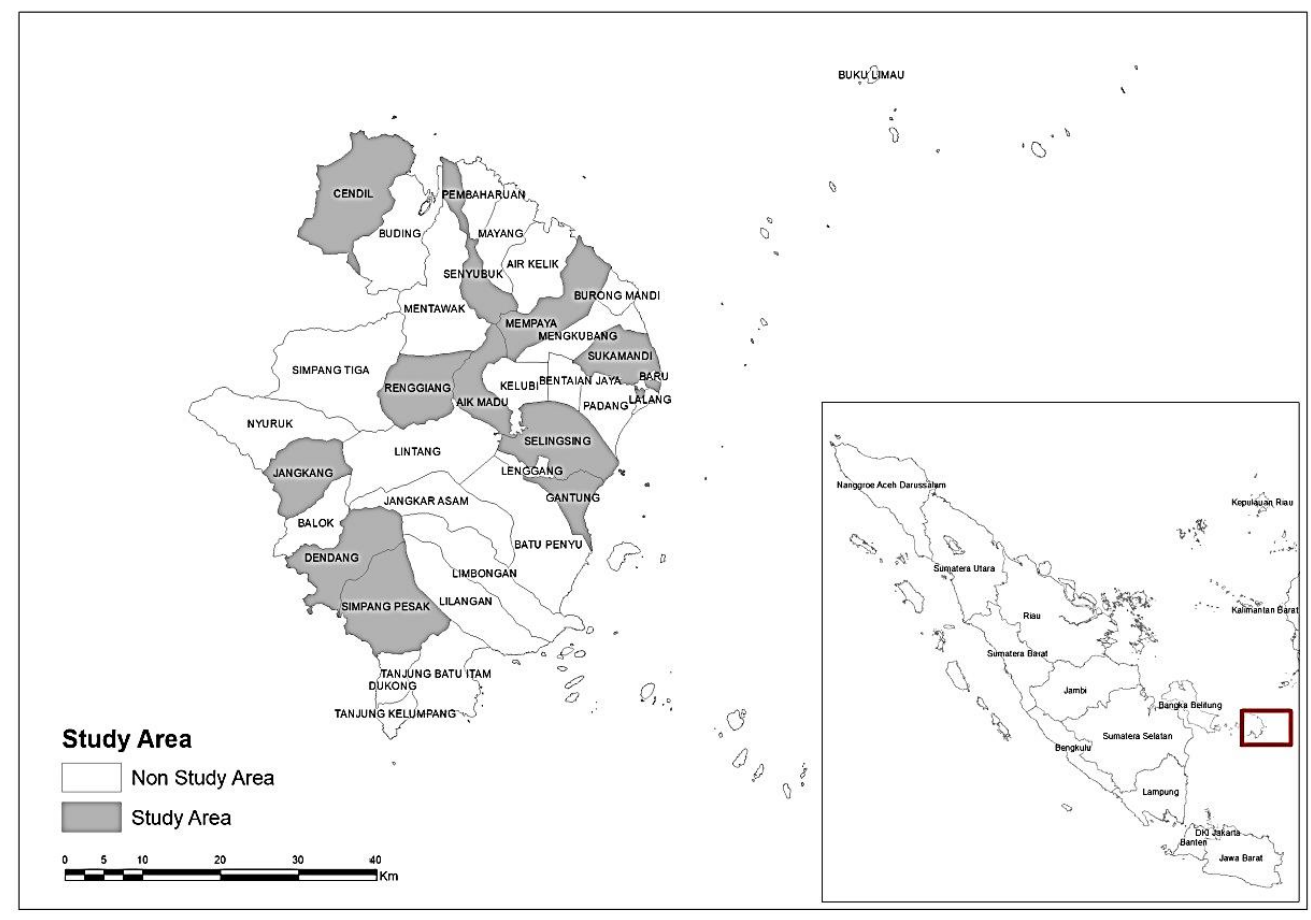

Figure 1 Maps of study area in East Belitung 


\section{RESULT AND DISCUSSION}

The socio-demographic conditions of the informants are shown in Table 1, indicating that traditional treatments are carried out more by males than females. This is in line with (Kayani et al. 2015), stating that the informants are mostly male by $95.86 \%$, while female was about $4.13 \%$. This result is in line with (Henri et al. 2020), stating that the informants are mostly male $(84 \%)$, compared to women $(16 \%)$ of the total 45 informants interviewed. Tchicaillat-Landou et al. (2018) also stated that male informants of shaman were 16 (80\%) compared to four women (20\%). However, Tarfaya Moroccan Province showed different result, i.e., women $(56.7 \%)$ used medicinal plants more dominantly than men (43.3\%) (Idm'Hand et al. 2020).

Table 1 shows that traditional healers or those who master traditional medicine in the East Belitung community, both Malays and local communities, are generally elderly. The number of people who have the skills and abilities of traditional medicine decreased in the young people, and it was not even found in the population aged < 29 years. The low number of people who have knowledge and ability of traditional medicine shows the low interest of the younger generation. This is because the younger generation is more easily affected by technological advances and the times, so that learning the legacy of knowledge in traditional medicine is not something that has to be studied anymore. In addition, the rapid development of pharmaceuticals using chemical products is easily found in pharmacies or stalls that sell medicines without a doctor's prescription. The current research is almost the same as research in Pakistan showing that the low knowledge of young groups about traditional medicine was caused by a lack of interest in studying and practicing it mainly due to globalization (Kayani et al. 2015). In addition, the low ability of young people related to traditional medicine, due to the ease of access to communication and practical use of chemical drugs, has caused young people to be reluctant to prepare traditional medicines (Utami et al. 2019). The same thing happened in the province of Tarfaya, southern Morocco, in which the younger groups knew less traditional medicine, due to their ignorance of the use of traditional medicinal plants (Idm'Hand et al. 2020). Knowledge of traditional medicine and its properties are generally obtained after long experience accumulated and transmitted from one generation to another. The transmission of this knowledge is in danger today because it is not always guaranteed. Previous studies have shown that the use of medicinal plants is greater among the 30 and 60 year age groups and has reported that this group is more susceptible to disease (El Azzouzi \& Zidane 2015).

The level of education of informants varies with the lowest level is elementary school, but those who know and have skills about traditional medicine graduated from higher education level. The number of informants with higher level of education decreases in line with the subsequent increase in education level (Table 1). Thus, it appears that the higher education that traditional healers have is inversely proportional to the number of those who have traditional medical knowledge and skills. This shows that traditional medical knowledge is not obtained through formal education but carried out with a culture handed down orally from previous generations. In general, traditional medicinal knowledge is a legacy of the nation's ancestors that has been used for generations for treatment and maintenance of health (Siswanto 2013). The level of education of informants who can deal with traditional medicine is slightly different from TchicaillatLandou et al. (2018), finding that in Congolese society, the level of education varied from uneducated (10\%), primary school $(20 \%)$, secondary school $(50 \%)$, and university $(20 \%)$. Thus, based on the level of formal education, the experience and knowledge of local people related to traditional medicine decrease in line with the increasing level of education. This indicates that people who have higher education pay less attention to the use of traditional medicines sourced from plants and animals (Kayani et al. 2015). This change seems to generally occur in all areas experiencing degradation. Local knowledge about traditional medicine and natural ingredients of medicine in the local community began to be displaced by modern medicine. Today, in line with the development of the market economy, the rise of sales of modern medicines from the city to the village and the increasing population cannot be denied. In addition, the reduced interest of the younger generation in terms of exploring and preserving local knowledge about traditional medicine as well as lack of local languages have caused the acceptance and dissemination of local knowledge about traditional medicine are less conveyed and gradually disappear. Besides, in general, parents who know medicinal plants do not play an active role in informally teaching to their children. Utami et al. (2019) mentioned that knowledge from parents also influences the ability to process medicinal plants.

Half of the informants have practiced traditional medicine $>20$ years. Meanwhile, $25 \%$ of the informant have practiced 10-20 years of traditional treatment experience, and only $3.57 \%$ of the information opened traditional medicine practices with the least experience of $<2$ years. Idm'Hand et al. (2020) stated that the informants aged > 50 years have the most knowledge about medicinal plants.

\section{Informant Knowledge Agreement on Each Category of Disease Type}

Informant Consensus Factor (ICF) for traditional medicines derived from plants and animals according to the informant can be divided into 12 categories based on the disease (Table 2). Many of the traditional medicine practitioners' informants were visited by consumers who mostly complained about respiratory disorders, muscle and bone disorders, as well as skin and heart disease. 
Table 1 Socio-economic characteristics of the informant

\begin{tabular}{cllcc}
\hline No. & Variable & Category & Informant (person) & Percentage (\%) \\
\hline 1 & Informant category & Traditional medicines & 20 & 71.43 \\
2 & \multirow{2}{*}{ Gender } & Local community & 8 & 28.57 \\
& & Male & 24 & 85.71 \\
3 & \multirow{2}{*}{ Age (years) } & Female & 4 & 14.29 \\
& & $30-39$ & 1 & 3.57 \\
& & $40-49$ & 6 & 21.43 \\
& & $50-59$ & 3 & 10.71 \\
4 & Education & $>60$ & 18 & 64.29 \\
& & No education & 0 & 0 \\
& & Elementary school & 20 & 71.43 \\
& & Junior high school & 4 & 14.29 \\
5 & Practical experience (years) & Senior high school & 3 & 10.71 \\
& & Diploma/undegraduate & 1 & 3.57 \\
& & $2-5$ & 1 & 3.57 \\
& & $5-10$ & 1 & 3.57 \\
\end{tabular}

Table 2 Informant Consensus Factor (ICF) value of traditional medicine from animal (A) and plant (F) material and type of disease treated

\begin{tabular}{|c|c|c|c|c|c|c|c|c|c|c|}
\hline \multirow{2}{*}{ Categories of diseases } & \multicolumn{2}{|c|}{$\begin{array}{c}\text { Number of } \\
\text { usage reports }\end{array}$} & \multicolumn{2}{|c|}{$\begin{array}{c}\text { Usage reports } \\
(\%)\end{array}$} & \multicolumn{2}{|c|}{$\begin{array}{c}\text { Number of } \\
\text { Species used }\end{array}$} & \multicolumn{2}{|c|}{$\begin{array}{c}\text { Species } \\
\text { amount }(\%)\end{array}$} & \multicolumn{2}{|c|}{ ICF } \\
\hline & A & $\mathbf{F}$ & $\mathbf{A}$ & $\mathbf{F}$ & $\mathbf{A}$ & $\mathbf{F}$ & $\mathbf{A}$ & $\mathbf{F}$ & $\mathbf{A}$ & $\mathbf{F}$ \\
\hline Indigestion & 10 & 159 & 11.91 & 39.07 & 8 & 97 & 12.5 & 34.4 & 0.22 & 0.39 \\
\hline Respiratory disease & 19 & 10 & 22.62 & 2.46 & 13 & 10 & 20.31 & 3.55 & 0.33 & 0 \\
\hline Muscle and Bone disorders & 5 & 37 & 5.95 & 9.09 & 4 & 27 & 6.25 & 9.57 & 0.25 & 0.28 \\
\hline Urinary disorders & - & 12 & - & 2.95 & - & 9 & - & 3.19 & - & 0.27 \\
\hline Sexual disease & 2 & 15 & 2.38 & 3.69 & 2 & 11 & 3.13 & 3.9 & 0 & 0.29 \\
\hline Gland abnormalities & 5 & 14 & 5.95 & 3.44 & 4 & 13 & 6.25 & 4.61 & 0.25 & 0.08 \\
\hline Ear, Nose, Eye Disease & - & 8 & - & 1.97 & - & 6 & - & 2.13 & - & 0.29 \\
\hline Nail, skin and hair diseases & 17 & 42 & 20.24 & 10.32 & 13 & 29 & 20.31 & 10.28 & 0.25 & 0.32 \\
\hline Nerve disorders & 1 & 10 & 1.19 & 2.46 & 1 & 8 & 1.56 & 2.84 & 0 & 0.22 \\
\hline Cardiovascular disorders & 1 & 45 & 1.19 & 11.06 & 1 & 30 & 1.56 & 10.64 & 0 & 0.34 \\
\hline Poison Antidote & 2 & 3 & 2.38 & 0.74 & 2 & 3 & 3.13 & 1.06 & 0 & 0 \\
\hline Energizing the body & 13 & 23 & 15.48 & 5.65 & 9 & 19 & 14.06 & 6.74 & 0.33 & 0.18 \\
\hline Infectious diseases & 5 & 20 & 5.95 & 4.91 & 4 & 17 & 6.25 & 6.03 & 0.25 & 0.16 \\
\hline Antidote & 4 & 3 & 4.76 & 0.74 & 3 & 3 & 4.69 & 1.06 & 0.33 & 0 \\
\hline
\end{tabular}

Based on the analysis of disease categories, it is grouped into 12 categories for traditional medicine from animals and 14 categories for plants (Table 2), showing that ICF values range between 0.00 to 0.39 . Disease categories such as sexual diseases, nerve disorders, cardiovascular disorders, and poison antidotes (ICF animals) as well as antidotes and respiratory diseases (ICF plant) get a zero value in the possibility of an agreement between informants on plants or animals used are very low due to the absence of information among the informants. The highest ICF value in plants (0.392) is in the category of digestive disorders, while the highest ICF value in animals is in the respiratory disease category and as an energizing the body where each ICF value is 0.33. People in East Belitung Regency believe that plants used as traditional medicines for digestive disorders such as abdominal pain, bloating, and ulcers vary greatly in line with the results obtained. According to Kayani et al. (2015) and Yabesh et al. (2014), indigestion is caused by poor environmental hygiene or water contamination which results in reduced drinking water quality. According to the informants, some animals are believed to be used to treat asthma such as grouse (Dendrocygna arcuata), dugong (Dugong dugon), velvet (Tapinauchenius gigas), retreat (Myrmeleon sp), keluang (Pteropus $s p$ ), sabak snake (Phyton reticulatus), scorpion (Heterometrus sp.), stratum (Tragulus sp.), cough (Belisarius xambeui) and ansu-ansu (Parapolybia varia). Rahman et al. (2016) stated that digestive disease starts from the visible in the mouth, and some herbs, shrubs 
and trees (16\%), whereas Lamiaceae with four species was the leading family, majority of medicinal plant

species used in the treatment of toothache $(38 \%)$, wound healing (19\%), gum infections (16\%). Meanwhile, the lowest percentage of species are used for mouth ulcers as well as teeth powder (3\%). If it is not treated quickly, respiratory disorders (asthma) are a common cause of illness and death. Alamgeer et al. (2018) found that people in Pakistan often experience health problems due to their remote location, cold and harsh climatic conditions, and scarce health care facilities. People rely on native plant resources to cure various disorders.

The second highest is cardiovascular disorders (0.34) with 45 reports of use and 30 types of plants. One type of cardiovascular diseases that is often experienced is hypertension. Some plants are used to treat hypertension, such as Chinese trident (Gymnanthemum amygdalinum), male exfoliate (Dicentra eximia), tad gadok (Leucas lavandulufolia), eggplant (Tinospora crispa), breadfruit (Artocarpus altilis), sisilen (Solanum rostratum), sire belande (Peperomia pellucida), meleman (Psychotria malayana), and snaps (Persicaria capitata). Riondato et al. (2019) found that in Madagascar communities the higher ICF values were recorded for cardiovascular complaints (0.75), general and unspecific diseases (0.74), digestive disorders (0.69), and diseases of the skin (0.55). The traditional medicinal uses of 18 species (15 endemic) were described for the first time.

\section{Medicinal Plant and Animal Conservation Strategies}

The SWOT analysis are carried out by analyzing internal and external factors towards the conservation of medicinal plants in East Belitung Regency (Table 3). Most of informants did not cultivate medicinal plants around their house, even some informants mentioned that medicinal plants could not be cultivated because the habitat and texture of the soil does not match with the forest habitat. There are few informants who try to cultivate medicinal plants collected from the forest to be planted in around the house. However, some of the plants are not able to survive. Our informants mentioned that medicinal plants are difficult to obtain, and we had to conduct a survey far away from home to find the medicinal plants. The presence of medicinal plants is still abundant in the forest but it is far inside the forest. The considerable distance to cover the forest is due to the fact that some of the forests close to housing have been converted into tin mining and oil palm plantations. This resulted in some medicinal plants that were in it are now damaged or even lost. Some animals used as medicine are also rather difficult to find in their natural habitat because the habitat is damaged by development, tin mining, and oil palm plantations.

Activities that need to be carried out are to conserve forests that still have a variety of medicinal plants and animals in them, so that they do not become extinct in their natural habitat. It is believed that plants and animals that are taken continuously without taking action will threaten the extinction of medicinal plants and animals. The extraction of medicinal plants and animals directly from nature without regarding the sustainability can cause scarcity and result in extinction (Henri et al. 2018). Therefore, some efforts need to be taken into action to develop medicinal plants and animals such as by increasing synergistic cooperation between conservation institutions and the community (Ledo \& Seran 2019). In addition, it needs to introduce medicinal species accompanied by conservation and outreach agencies to carry out their cultivation to the local community to be more concerned about the potential of medicinal plants and the preservation of medicinal animals (Ledo \& Seran 2019). Appropriate conservation strategies such as grazing control, reforestation, and rangeland management can be adopted to promote the sustainable use of traditional medicines (Murad et al. 2013).

Environmental education in the community in East Belitung Regency can be implemented by providing learning materials containing knowledge on animal ecology, plant ecology, the impact of animal hunting, and forest destruction on the sustainability of the ecosystem (Sayektiningsih \& Mediawati 2017). Increasing the interest of young people in the use of traditional medicines can be done by making products made from plants and animals as medicines that are easy to consume and whose properties are scientifically proven. In addition, the role of shamans as traditional leaders is very essential in maintaining forest sustainability in East Belitung Regency due to land clearing. In this case, shamans can act as guardians of the region, for example people who want to open an area must follow the procedures established by the shamans to ensure the area does not include the prohibited forest or forest in which there are occult spirits (Wildan \& Irwandi, 2018). When the shaman has forbidden opening the area, then the person or the community will not dare to violate it. If there are people who break them, there will be risks such as illness, accident to the workers, being failed in the business, and even death. The effort to preserve a certain forest area by the local community is not based on the awareness of the community itself but is related to sanctions and disasters that occur accepted if it destroys the area (Wildan \& Irwandi 2018). 
Table 3 SWOT analysis of plants and animals as medicine

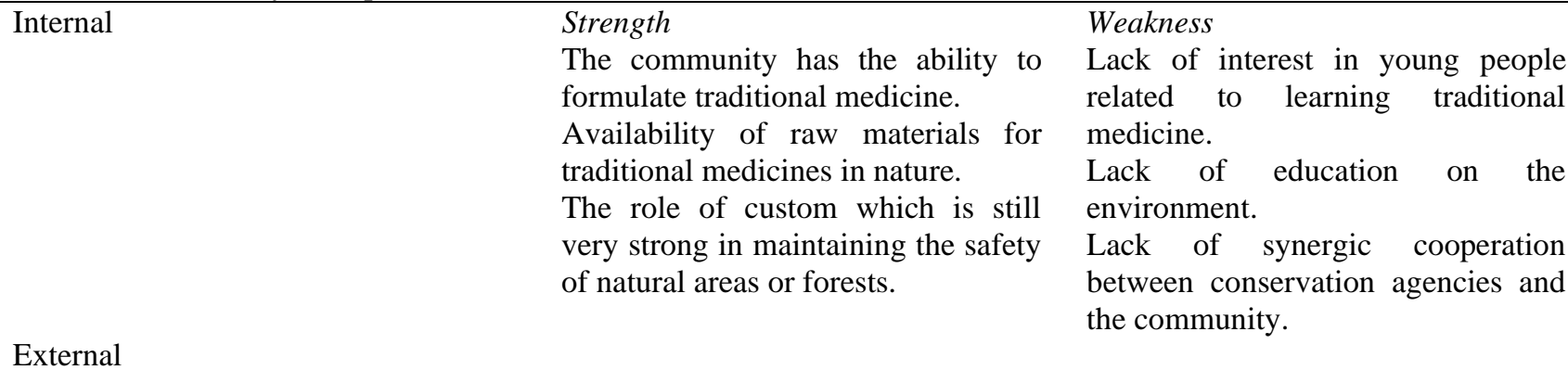

Opportunity
The quality of the environment
decreases causes plants and animals to
become extinct, so that conservation
activities are applied.
The establishment of Geopark as a
geological heritage to protect the
diversity of the earth, environmental
conservation, and provide employment
opportunities for the community.
Increasing the market for medicinal
plants and animals

Threat
Conventions on forest land into open
land are increasing.
Community knowledge is still low on
the protection of certain species.
Excessive use of medicinal plants and
animals without any conservation
efforts
Strategy S-O
Conducting promotional activities to increase community income.
The availability of raw materials in nature that are easily obtained provides opportunities for the community to make traditional medicinal products for income. Maintaining forest safety by obeying the orders of traditional leaders

\section{Strategy W-O}

Providing knowledge about the use and procedures of plants and animals as a medicine for young people so that they will not disappear in the future.

Socializing the importance of environmental education in the community

Enhancing cooperative relationships with communities with conservation institutions

Strategy S-T Strategy W-T

Maintaining a forest that still has a Providing social sanctions for diversity of medicinal plants in it. communities that damage forests Using plants and animals as where biodiversity exists. medicine wisely. Increasing community income by growing plants and animals as medicine.

Development of human resources around the conservation area.

\section{CONCLUSION}

The local community in East Belitung Regency is currently still applying traditional medicine in their daily life. The use of plants and animals as medicine is more widely known by people aged $>60$ years with an average duration of use $>20$ years compared to the age level at a young age. Forest preservation is one of the conservation strategies that can be applied, this is because the forest still has a variety of medicinal plants and animals in it which can be used as a source of community medicine.

\section{ACKNOWLEDGEMENT}

We would like to thank all those who have contributed to this research, especially the people of East Belitung Regency for the information provided. We also thank the Biology Laboratory of Universitas Bangka Belitung and Herbarium Bangka Belitungense (HBB) for the identification process during the research.

\section{REFERENCES}

Addoun N, Delattre C, Boual Z. 2018. Ethnic Medicine and Ethnobotany Concept to Identify and Characterize New Polysaccharide-Based Drug from Arid and Semi-Arid Lands. Advances in Applied Chemistry and Biochemistry. 1(1): 37-39. http://doi.org/10.33513/acbc/1801-05

Adorisio S, Fierabracci A, Rossetto A, Muscari I, Nardicchi V, Liberati AM, Delfino DV. 2016. Integration of traditional and Western medicine in Vietnamese populations: A review of health perceptions and therapies. Natural Product Communications. 11(9):1409-1416. http://doi.org/10.1177/1934578x1601100949

Afriyansyah B, Hidayati N, Aprizan H. 2016. Pemanfaatan hewan sebagai obat tradisional oleh Etnik Lom di Bangka. Jurnal Penelitian Sains. 18(2):66-74.

Alamgeer, Younis W, Asif H, Sharif A, Riaz H, Bukhari IA, Assiri AM. 2018. Traditional medicinal plants 
used for respiratory disorders in Pakistan: A review of the ethno-medicinal and pharmacological evidence Milen Georgiev, Ruibing Wang. Chinese Medicine. 13(48):1-29. http://doi.org/10.1186/s13020-0180204-y

Alves RRN, Souto WMS. 2011. Ethnozoology in Brazil: Current status and perspectives. Journal of Ethnobiology and Ethnomedicine. 7:1-18. http://doi.org/10.1186/1746-4269-7-22

Ansari J, Inamdar N. 2010. The promise of traditional medicines. International Journal of Pharmacology. 6(6):808-812.

Butt MA, Ahmada M, Fatima A, Sultana S, Zafar M, Yaseen G, Kayani S. 2015. Ethnomedicinal uses of plants for the treatment of snake and scorpion bite in Northern Pakistan. Journal of Ethnopharmacology. 168:164-181. http://doi.org/10.1016/j.jep.2015.03.045

El Azzouzi, F, Zidane L. 2015. La flore médicinale traditionnelle de la région de Béni- Mellal (Maroc). Journal of Applied Biosciences. 91(1):8493. http://doi.org/10.4314/jab.v91i1.8

Faruque MO, Uddin SB, Barlow JW, Hu S, Dong S, Cai Q, Hu X. 2018. Quantitative ethnobotany of medicinal plants used by indigenous communities in the Bandarban district of Bangladesh. Frontiers in Pharmacology.

$9: 1-12$. http://doi.org/10.3389/fphar.2018.00040

Henri H, Hakim L, Batoro J. 2018. Kearifan lokal masyarakat sebagai upaya konservasi Hutan Pelawan di Kabupaten Bangka Tengah, Bangka Belitung. Jurnal Ilmu Lingkungan. 16(1):49-57. http://doi.org/10.14710/jil.16.1.49-57

Henri H, Nababan V, Hakim L. (2020). Ethnobotanical study of early childhood medicinal plants used by the local people in South Bangka Regency, Indonesia. Biosaintifika: Journal of Biology \& Biology Education. $\quad$ 12(3): 414-421. http://doi.org/http://dx.doi.org/10.15294/biosaintifika. v12i3.22221

Idm'Hand E, Msanda F, Cherifi K. 2020. Ethnobotanical study and biodiversity of medicinal plants used in the Tarfaya Province, Morocco. Shengtai Xuebao/ Acta Ecologica Sinica. 40(2):134-144. http://doi.org/10.1016/J.CHNAES.2020.01.002

Iskandar J. 2016. Etnobiologi dan keragaman budaya di Indonesia. Umbara. 1(1):27-42. http://doi.org/10.24198/umbara.v1i1.9602

Kayani S, Ahmad M, Sultana S, Khan Shinwari Z, Zafar M, Yaseen G, Bibi T. 2015. Ethnobotany of medicinal plants among the communities of Alpine and Sub-alpine regions of Pakistan. Journal of Ethnopharmacology. 164: 186-202. http://doi.org/10.1016/j.jep.2015.02.004

Kim H, Song MJ. 2013. Ethnozoological study of medicinal animals on Jeju Island, Korea. Journal of Ethnopharmacology. http://doi.org/10.1016/j.jep.2012.11.011
Ledo S, Seran W. 2019. Keanekaragaman tumbuhan obat Taman Wisata Alam Baumata Kabupaten Kupang serta Pemanfaatannya oleh masyarakat lokal. Agrikan: Jurnal Agribisnis Perikanan. 12(2):299310. http://doi.org/10.29239/j.agrikan.12.2.299-310

Murad W, Azizullah A, Adnan M, Tariq A, Khan KU, Waheed S, Ahmad A. 2013. Ethnobotanical assessment of plant resources of Banda Daud Shah, District Karak, Pakistan. Journal of Ethnobiology and Ethnomedicine. 9(1), 1-10. http://doi.org/10.1186/1746-4269-9-77

Narchi NE, Cornier S, Canu DM, Aguilar-Rosas LE, Bender MG, Jacquelin C, de Wit R. 2014. Marine ethnobiology a rather neglected area, which can provide an important contribution to ocean and coastal management. Ocean and Coastal Management. 89:117-126. http://doi.org/10.1016/j.ocecoaman.2013.09.014

Oktavia D. 2012. Komposisi Vegetasi dan potensi tumbuhan obat di Hutan Kerangas Kabupaten Belitung Timur Provinsi Kepulauan Bangka Belitung. Bogor: IPB.

Oyeyemi IT, Akinseye KM, Adebayo SS, Oyetunji MT, Oyeyemi OT. 2019. Ethnobotanical survey of the plants used for the management of malaria in Ondo State, Nigeria. South African Journal of Botany. 124:391-401. http://doi.org/10.1016/j.sajb.2019.06.003

Permenkes. 2012. Peraturan Menteri Kesehatan Republik Indonesia Nomor 006 Tahun 2012 Tentang Industri dan Usaha Obat Tradisional.

Rahman IU, Ijaz F, Iqbal Z, Afzal A, Ali N, Afzal M, Asif M. 2016. A novel survey of the ethno medicinal knowledge of dental problems in Manoor Valley (Northern Himalaya), Pakistan. Journal of Ethnopharmacology. 194:877-894. http://doi.org/10.1016/j.jep.2016.10.068.

Riondato I, Donno D, Roman A et al (2019) First ethnobotanical inventory and phytochemical analysis of plant species used by indigenous people living in the Maromizaha forest, Madagascar. $J$ Ethnopharmacol. 232:73-89.

Saudah S, Rasnovi S, Zumaidar Z. 2019. Tingkat pengenalan masyarakat terhadap jenis tumbuhan obat Di Kecamatan Peusangan Selatan Kabupaten Bireun. Jurnal Serambi Engineering. 4(1):392. http://doi.org/10.32672/jse.v4i1.849

Sayektiningsih T, Mediawati I. 2017. Menuju pemanfaatan lestari satwa liar berkhasiat obat. Seminar Nasional Biologi (SEMABIO):769-784.

Shuaib M, Ahmed S, Ali K, Ilyas M, Hussain F, Urooj Z, Hussain F. 2018. Ethnobotanical and ecological assessment of plant resources at District Dir, Tehsil Timergara, Khyber Pakhtunkhwa, Pakistan. Acta Ecologica Sinica. 39(1):109-115. http://doi.org/10.1016/j.chnaes.2018.04.006

Siswanto. 2013. Saintifikasi jamu sebagai upaya terobosan untuk mendapatkan bukti ilmiah tentang 
manfaat dan keamanan jamu. Buletin Penelitian Sistem Kesehatan. 15(2):203-211. http://doi.org/10.22435/bpsk.v15i2Apr.2994

Tchicaillat-Landou M, Petit J, Gaiani C, Miabangana ES, Kimbonguila A, Nzikou JM, Matos L. 2018. Ethnobotanical study of medicinal plants used by traditional healers for the treatment of oxidative stress-related diseases in the Congo Basin. Journal of Herbal Medicine. 13:76-90. http://doi.org/10.1016/j.hermed.2018.05.002

Utami RD, Zuhud EAM, Hikmat A. 2019. Medicinal ethnobotany and potential of medicine plants of Anak Rawa Ethnic at The Penyengat Village Sungai Apit Siak Riau. Media Konservasi. 24(1):40-51. http://doi.org/10.29244/medkon.24.1.40-51

Verma AK, Prasad SB, Rongpi T, Arjun J. 2014. Traditional healing with animals (zootherapy) by the major ethnic group of Karbi Anglong district of Assam, India. International Journal of Pharmacy and Pharmaceutical Sciences. 6(8):593-600.

Vijayakumar S, Morvin Yabesh JE, Prabhu S, Ayyanar M, Damodaran R. 2015. Ethnozoological study of animals used by traditional healers in Silent Valley of Kerala, India. Journal of Ethnopharmacology. 162:296-305.

http://doi.org/10.1016/j.jep.2014.12.055

Vitalini S, Iriti M, Puricelli C, Ciuchi D, Segale A, Fico G. 2013. Traditional knowledge on medicinal and food plants used in Val San Giacomo (Sondrio, Italy) - An alpine ethnobotanical study. Journal of Ethnopharmacology. 145(2):517-529. http://doi.org/10.1016/j.jep.2012.11.024

Wildan AD, Irwandi I. 2018. Peran dukun kampung dalam kehidupan masyarakat melayu belitung. Kelola: Jurnal Ilmu Sosial. 1(1):1-16. http://doi.org/10.15575/jk.v1i1.3764

Witjoro A, Sulisetijono, Setiowati FK. 2016. Pemanfaatan tanaman obat di Desa Kayukebek, Kecamatan Tutur, Kabupaten Pasuruan. Natural B. 3(4):303-310. http://doi.org/S0741-5214(07)00989-5 [pii]

Woerdenbag HJ, Nguyen TM, Vu D Van, Tran H, Nguyen DT, Tran T. Van, Brouwers JR. 2012. Vietnamese traditional medicine from a pharmacist's perspective. Expert Review of Clinical Pharmacology. 5(4):459-477. http://doi.org/10.1586/ecp.12.34

Yabesh JE, Prabhu S, Vijayakumar S. 2014. An ethnobotanical study of medicinal plants used by traditional healers in silent valley of Kerala, India. Journal of Ethnopharmacology. 154(3):774-789. http://doi.org/10.1016/j.jep.2014.05.004

Zahara N. 2017. Kajian etnobiologi tanaman obat Masyarakat Meunasah Rayeuk, Lamno Kabupaten Aceh Jaya. In Prosiding Seminar Nasional Biotik. 362-366). 